\section{Featured EIF Publication}

\section{The Ceremonial Center of Orongo, by Alan Drake}

In 1992, a small book focusing on the ceremonial center of 'Orongo was published by the Easter Island Foundation and promptly fell into oblivion. This was a surprise to the Foundation and also to the author, the late great Alan Drake, and illustrator, Georgia Lee. Both had become fascinated and enchanted by 'Orongo with its vistas, carved rocks, and layers of history.

The book describes Complex A, the 'Orongo village and Mata Ngarau, the sacred precinct where most of the petroglyphs are concentrated. We first learn about the historical inquiries starting with J. L. Palmer who was there in 1868, and who carried off the famous statue, Hoa Hakananai'a to England, where it is still on display in the British Museum.

Other famous visitors studied the site, such as Katherine Routledge, who arrived to the island in 1914, and Henri Lavachery who was there with Alfred Métraux in 1935. In 1955-56, the Norwegian Expedition's Edwin Ferdon worked here, particularly the area known as Complex A. In the mid-1970s, William Mulloy began to restore the houses and pathways. Beginning in 1981, a total of 1,449 petroglyphs at 'Orongo and environs were documented by Lee, including some on the islet of Motu Nui.

One chapter details the construction of the stone houses at 'Orongo village, followed by chapters on Mata Ngarau, the Birdman Cult, Motu Nui, Mataveri, Vai Atare and the caldera. Also included are: "Orongo as it Was" and "Orongo Artifacts in Museums" and "Hints on Savoring Orongo". There are suggestions for taking photos, and finally, an afterword.

The end matter includes notes, bibliography, references, maps, a Rapanui Glossary, and an index. There are numerous pages of black and white photographs showing the crater, aerial views, historical drawings by various visitors, detailed drawings and photographs of the petroglyphs, the stone houses, rongorongo boards, and paintings on the ceiling of the cave Ana Kai Tangata. There are also drawings of petroglyphs from other sites around the island, including the extraordinary petroglyph boulder at Rano Kau and two of 'Orongo's boulders that are now in the collection of the Peabody Museum, Cambridge, MA.

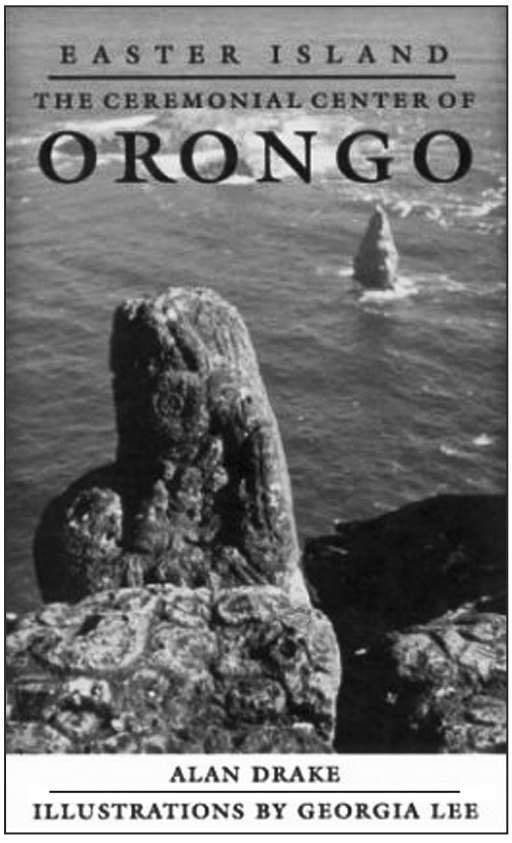

Since this book was published, the site of 'Orongo has become unstable and public access is limited. Due to its perilous location on the edge of a cliff, the situation at 'Orongo is not expected to improve; it is feared that portions of the site may someday tumble into the sea below. Studies are being conducted to preserve the site and prevent further erosion.

The book is 6x9" format, 100 pages, and is illustrated with numerous black and white photographs, as well as drawings by Georgia Lee.

This book is an excellent resource for anyone wanting to learn about the ceremonial center of 'Orongo. We are offering the book at a special discount price of $\$ 10$ to our readers. Please contact the EIF office to order (books@islandheritage.org). 